\title{
Moet ons die Belydenis van Belhar (1986) as 'n nuwe Belydenisskrif aanvaar ${ }^{1}$ ?
}

A C J van Niekerk

\section{ABSTRACT}

Can we accept the Confession of Belhar (1986) as a new doctrinal confession?

The possibility exists that the Dutch Reformed Church (DRC) could stop the process of church unity in its own family due to its refusal to accept The Confession 1986 (Confession of Belhar) as a fourth reformed confession. In this article the question of acceptance is examined from four perspectives and it is concluded that it should be accepted if the DRC wants to gain credibility. First the nature, characteristics and history of confessions oblige the Church in difficult situations to adopt new confessions. Secondly the history of the DRC and its family makes it imperative to overcome the gulf between believers from the same tradition through the "language of confession". Thirdly the main contents of the confession is biblically sound while absolutism of different kinds is avoided. Lastly it is argued that the confession satisfies the requirement for both contextual relevance and universal applicability.

\section{INLEIDING}

In die poging tot eenwording deur die Ned Geref Kerk familie sal Die Belydenis 1986 (ook genoem Belydenis van Belhar) waarskynlik die "steen des aanstoots" word. Die debat oor eenwording sal beslis vurig, maar hopelik ook diepsinnig verloop. Die basiese vraag is of ons die Belydenis kan aanvaar as ' $n$ vierde belydenisskrif.

Daar is talle lidmate wat vra: Kan ons Die Belydenis 1986 nie net as 'n beleidsdokument aanvaar (soos bv Kerk en Samelewing) nie? Moet ons dit as 'n belydenisskrif op dieselfde vlak as die drie formuliere aanvaar? Ek wil die vrae beantwoord deur eerstens na die doel, aard en funksie van 'n belydenis te verwys; daarna die historiese agtergrond van die Belydenis 1986 in ag te neem; derdens die inhoud met Bybelse gegewens te vergelyk en laastens na te gaan of die Belydenisskrif blywende betekenis sal hê. 


\subsection{Die betekenis van die term "Belydenis"}

Hoewel die betekenisveld van "belydenis" geweldig wyd is, is daar 'n neiging om die begrip op ten minste drie maniere te verstaan ${ }^{2}$ :

- Eerstens dui belydenis op 'n spontane, dikwels persoonlike, maar beslis 'n situasiegebonde belydenisdaad (confessio). "Von Hause aus ist das Bekenntnis ein Geschehen, keine Urkunde", volgens Weber ${ }^{3}$.

- Tweedens kan belydenis dui op 'n skriftelike of mondelinge belydenisformule wat die eie ontstaansituasie transendeer om 'n gesamentlike geloofsverstaan daar te stel (symbolum). (Bv ons ekumeniese belydenisskrifte).

- Derdens kan belydenis ook verstaan word as die leeruitsprake van 'n kerkgemeenskap waardeur eie identiteit afgegrens word (doctrina) (Bv die drie formuliere van eenheid).

Hoewel 'n Christelike belydenis sy kernformulering in die NuweTestamentiese belydenis van "Jesus is die Here" het, is daar 'n voortgaande proses van belydenis juis omdat $\mathrm{Hy}$ wat bely word, die vleesgeworde en die teenwoordige Christus is en nuwe bedreiginge van binne en buite die kerk in hierdie wêreld plaasvind. Die Gees van die Vader en Seun vergesel die kerk deur die eeue en wil steeds deur middel van belydenisvorming die kerk help om 'n suiwere identiteit te behou. Ons mag die Heilige Gees se werking nie tot 'n tyd, byvoorbeeld die Reformasietyd, beperk nie.

\subsection{Die karakter van 'n belydenis}

In die drie soorte belydenisse wat ons onderskei, is daar twee inherente aspekte (karaktertrekke) wat in spanning met mekaar verkeer, naamlik: (i) historiese aktualiteit en (ii) bo-historiese kwaliteit.

Watter soort belydenis ontstaan, watter aspek hoofklem kry en hoedanig die uitwerking is word grotendeels deur die betrokke situasie (Sitz im Leben) bepaal. Dit hang saam met die veronderstelling dat alle teologie in 'n sin kontekstueel is, dit wil sê vanuit 'n bepaalde samelewingskonteks beoefen word. Die eie aard van 'n belydenis vereis 
dat, meer eksplisiet as in ander vorme van teologisering, die waarheid van die Christelike geloof in ' $n$ bestemde tyd en situasie duidelik uitgespel moet word. ' $n$ Belydenis is daarom 'n tendensgeskrif. Dit bevat nie die ganse geloof wat dit bely nie. Dit geld selfs ook belydenisskrifte waarin die afwysende funksie nie die hoofklem kry nie, soos byvoorbeeld die Apostoliese Geloofsbelydenis. Weinig word oor die Heilige Gees bely omdat die kwessies toentertyd oor Christus en nie oor die Gees gehandel het nie.

\subsection{Die funksie van 'n belydenis}

Terwyl die belydenis ' $n$ wesenlike historiese karakter het en daarom die kerugma wil laat pyl op 'n spesifieke situasie, het dit ook 'n bo-historiese kwaliteit en verwys daarom nie net na spesifieke verbygaande fenomene nie. Heyns ${ }^{4}$ beskryf hierdie tweeledige handeling in belydenisvorming heel korrek in dinamiese terme, naamlik 'n "onthistorisering" en "verhistorisering". Hierdie dubbele, ja selfs teenstrydige funksie, moet in gedagte gehou word by die interpretasie van belydenistaal.

Schwarz ${ }^{5}$ onderskei ten minste ses funksies van 'n belydenisskrif: selfdefiniërings-, gemeenskaps-, afgrensings-, kerugmatiese-, doksologiese- en kategetiese funksies. Hierdie funksies kan vir die doeleindes van ons besinning in twee basiese funksies saamgevat word, naamlik (i) 'n opbouende en versterkende doel en (ii) 'n afwysende en afgrensende doel.

Dikwels, soos in die geval van Die Belydenis 1986, word beide funksies benut.

\subsection{Die geskiedenis van Gereformeerde Protestantisme se belydenis- vorming}

Die Gereformeerde belydenisskrifte (Heidelbergse Kategismus; Dordtse Leerreëls; Nederlandse Geloofsbelydenis) het net soos die Ekumeniese belydenisse of simbole (Apostoliese Geloofsbelydenis; Nicea-Konstantinopel; Athanasius) 'n bepaalde ontwikkeling gehad.

In die Gereformeerde Protestantisme was die eerste belydenisskrifte selektief gerig om getuienis af te lê teenoor buitestaanders, maar veral om informasie te gee teenoor volgelinge oor bepaalde aktuele sake waaroor onduidelikheid bestaan het. Die belydenisse word later uitgebrei tot kategismusse wat op populêre wyse die hele inhoud van die geloof vir mense in bepaalde omstandighede wou oordra. Calvyn en Ursinus word as die belangrikste verteenwoordigers van dié Gereformeerde gebruik deur 
Augustijn voorgehou6. Die bedoeling was nie om met dwang ander ketterye af te wys nie, maar om 'n eenheidsband te bied.

Later het die inhoud volgens Augustijn al hoe minder 'n getuienis of kategismus geword, maar 'n uitgewerkte dogma. Die gesagskarakter het gevolglik ook dié van 'n saambindende getuienis geword en die Gereformeerdes wat, in elke land hul eie geloofsbelydenis gehad het, het mekaar se belydenisskrifte erken. Vanaf 1580 het in Suid-Nederland die saambindende getuienis-karakter verander in 'n "formulier" of 'n "kerklike wet" met bindende gesag. Die klem het al hoe minder op die "eenheid der leer" geval en was al meer daarop gemik om "de gezondheid" van die leer te waarborg?.

Vir die kinders van Dordt het die belydenis met die ondertekeningsformulier volgens Augustijn 'n dwanginstrument geword. Daarby is belydenisse kunsmatig onderhou terwyl hul aktualiteit reeds verby was ${ }^{8}$.

\subsection{Sosio-politieke konteks}

Omdat die sosio-politiese konteks 'n wesenlike invloed uitoefen op die gesag van die teks, moet die ontstaansituasie van die voortbestaansituasie onderskei word. Calvyn het byvoorbeeld die situasie van elke belydenis in ag geneem. Indien daar nie met die historiese ontstaanomstandighede rekening gehou word nie, kan 'n belydenis se gesag as norma normans in plaas van norma normata gesien word. Die "skopiese" en "periferiese gesag" van 'n belydenis moet volgens Heyns behoorlik in ag geneem word 9 .

Die Nederlandse Geloofsbelydenis se ontstaansituasie was nie bloot om godsdienstige redes nie. Die bedoeling was onder meer om aan die hoofsaaklik Roomse publiek en Roomse leierskap van destyds te toon dat die Calvinistiese beweging 'n nie-dopperse en 'n nie-rewolusionêre gees gehad het ${ }^{10}$.

Die Heidelbergse Kategismus het in 'n politieke klimaat ontwikkel. Dié Kategismus is 'n voorbeeld van 'n letterlik begrensende territoriale belydeniskeuse van keurvors Friedrich III. Hy het probeer om sy heersersgebied "... von aller 'unrichttigkeit un ungleichheit' der Lehre zu befreien und die notwendige Verbesserung anzustellen", aldus Wirsching11. Augustijn ${ }^{12}$ meen dat die vroom, maar deur Lutherane gehate, Friedrich III moes toon dat hy deel is van 'n groter groep gereformeerdes in die buiteland om daardeur Keiser Maximilaan II se 1565-maatreëls teen die Calvinisme teë te werk.

Deur ' $n$ belydenis se ontstaan bloot op grond van sy politieke-sosiale konteks te veroordeel, sal veroorsaak dat ons weinig belydenisse sal 
oorhou. Ons moet waak teen 'n dosetisme (ontkenning van die menslikheid van God se openbaring en van geloofsuitsprake met vroomklinkende argumente). God inkarneer in Jesus. Hy kan menslike omstandighede en middele gebruik en ten goede laat meewerk.

\subsection{Die noodsaak van 'n belydenis}

Wanneer die ontwikkeling van die belydenisgesagopvatting en die absolutisme waarheen dit in sommige gevalle gelei het nagegaan is, is die teenkanting wat in die eeu van die ekumene teen belydenisvorming gekom het, te verstane. Bucer, Calvyn se leermeester in Strassburg, se huiwering in die opstel van 'n geloofsbelydenis vir sy stad is vandag nog ter sake. Geloof en ook geloofseenheid moet volgens hom op die Woord van God gebou wees. Die menslike verstand is nie in staat om God se Woord voldoende te kan saamvat nie en weens menslike onbestendighede kan geloofseenheid nie op mensewoorde gebou word nie. Bowendien, wie nie voor God se Woord wil buig nie, sal volgens Bucer ook nie voor mensewoorde buig nie. Indien 'n belydenis noodsaaklik is, dan moet dit kort en woordeliks uit die Bybel opgestel word ${ }^{13}$. Weber ${ }^{14}$ meen dat 'n belydenis hulp moet verleen om juis weer die Skrif reg te verstaan. Heyns' 15 waarsku teen 'n "aktualisme", maar erken dat dit prinsipieel en prakties noodsaaklik is dat nuwe belydenisskrifte gevorm moet word sodat die Skrifboodskap vir ons tyd verstaan kan word.

Nuwe belydenisskrifte kan dus nie prinsipieel afgewys word nie. Die vraag is wanneer sou teologiese gesprekstaal nie meer voldoende wees nie en moet belydenistaal aangewend word? Van Huyssteen ${ }^{16}$ onderskei tussen geloofs-, belydenis- en teologiese uitsprake. Teologiese taal het 'n argumentatiewe en kritiese karakter terwyl geloofstaal en ook konfessionele taal ' $n$ beslissings- en antwoordkarakter het. Konfessionele taal is ' $n$ taalvorm tussen die metaforiese aard van geloofstaal en die konseptuele aard van teologiese taal. Vir hierdie besondere mengsel van metaforiese en konseptuele taal meen Van Huyssteen dat die begrip "model" geskik is. So 'n model moet aan twee vereistes voldoen. Eerstens moet dit insiggewend wees deurdat dit probleme moet help oplos. Tweedens moet so 'n model geloofservaringe kan verwoord. Die voordeel van 'n belydenis as denkmodel in onderskeid van geloofstaal en teologiese taal is dus dat dit 'n belangrike brug tussen die twee vorm. Daarby is dit noodsaaklik vir vooruitgang in probleemoplossing in gelowige denke en is dit tekenend van die vitalistiese aard van geloof wat deurdenk word.

Besonder waardevol by Van Huyssteen is die de-absolutering van belydenis en ook elke ander vorm van teologiese uitsprake. Geen 
teologiese uitspraak is absoluut en volledig nie. Enersyds waarsku Van Huyssteen dus teen konfessionalisme. Andersyds is die modelkarakter van die belydenis ' $n$ noodsaaklike interpretasiemiddel waardeur bepaalde ervaringe op 'n beslissende wyse oorgedra kan word ten einde bepaalde probleme te help oplos.

Die positiewe bydrae wat belydenistaal in ons huidige situasie kan lewer, is noodsaaklik. As betekenistaal wat nie in die eerste plek intellektueel skerpsinnig wil wees nie, maar ook nie ongeldige uitsprake wil maak as 'n "brug" tussen "geloofstaal" en "teologiese taal" nie (Weber $)^{17}$, kan dit nie 'n brug van verstaan tussen twee wêrelde in een land help vorm nie? Dit kan tog die probleem oplos van teologiese taal wat bymekaar verby gepraat het. Dit kan as model daarin slaag om geloofstaal weer so te verwoord dat dit deur beide groepe verstaan word.

\section{3 'N KORT HISTORIESE AGTERGROND}

Die ontstaan van 'n nuwe Belydenis kan alleen verstaan word vanuit die ervaring van Christene van die voormalige Nederduitse Gereformeerde Sendingkerk (voortaan: Sendingkerk). Ruimte ontbreek om die hartseergeskiedenis, wat deur sommige historici verromantiseer is, hier te probeer verwoord ${ }^{18}$. Kortliks saamgevat kan dit soos volg verduidelik word:

Kleurvooroordeel en swak kerkbegrip gee aanleiding tot die vorming van aparte etniese kerke (1881). Hierdie antropologiese en ekklesiologiese gebreke sou vir meer as 'n eeu 'n groot invloed uitoefen. Terwyl vir die ekklesiologiese gebreke gekompenseer is met sendingbewussyn en later ook 'n sendingteologie is die antropologiese gebreke versluier met ('n wit) volksbewussyn en later ook 'n volksteologie. Die gebreke in die moederkerk se teologiese mondering was gekamoefleer - die kerk het in die algemeen sukses gesmaak en van "sendingseën" getuig. Omdat die ekklesiologiese basis swak was, het dit veral die sendingbeleid benadeel. Die daarbygevoegde swak antropologiese basis het veroorsaak dat nie alleen die sendingbeleid nie, maar ook die samelewingsbeleid regstreeks beïnloed is. Van binne die moederkerk sou daar wel deurgaans protes van dapper enkelinge wees, maar dit sou veral die oudste "dogter" wees wat die sterkste protes sou maak. Die protes sou na net meer as 'n eeu uitloop op die aankondiging van status confessiones en die Belhar konsepbelydenis in 1982. Na nog 'n rondte teleurstellende antwoorde deur die Ned Geref Kerkleierskap van daardie tyd, wat getoon het dat die erns van hulle ervaring onderskat is, is Die Belydenis 1986 eenparig as volwaardige belydenis deur die Sendingkerk se sinode aanvaar. 
'n Enkele verdere opmerking: Die protes van meer as 'n eeu deur Christene van die "Moederkerk" en die "Sendingkerk" moet nie bloot as politiekery gesien word nie. Die oudste vorm van protes wat opgespoor is, is die van ds D P M Huet in 1860 - dit wil sê drie jaar na die veelbesproke sinodebesluit van 1857. Volgens Huet: "Het is een vreeselijk denkbeeld dat mannen voorstanders van de kerk des Heeren, die daar zitten om de belangen van het Godsrijk op aarde te overwegen en te behartigen, bepalingen maken omtrent de inrigting der kerk, naar eigene inzigten. Gewoonlijk in kerkelijke questien zoekt men de uitspraak der Schrift te weten en zich daaran te houden. Of wel, he geen ook geschiedt, zijne eigene meening te volgen en dan uit de Schriften goed te maken. Doch hierin bepaalt men eerst hoe de Schrift het wil en dan hoe men tegen den wil der Schrift handelen mag" ${ }^{19}$.

\section{IS DIE INHOUD VAN DIE BELYDENIS BYBELS?}

Die belydenis bestaan uit vyf artikels wat handel oor geloof in God, kerkeenheid, versoening, geregtigheid en volharding in die belydenis. In die middelste drie artikels word drie basiese waarhede onderstreep en enige lewensstyl wat dit teëgaan, verwerp:

- God wil één kerk hê en die eenheid moet sigbaar en werksaam wees.

- God kan en wil Christene wat versoen is met Hom in staat stel om werklik versoen met mekaar te lewe en 'n invloed op die samelewing uit te oefen.

- God is die God van geregtigheid: Hy is die hulp van die hulpelose en Hy roep sy kerk om Hom daarin te volg.

Dit is ooglopend dat die Belydenisteks grootliks op Skrifgedeeltes gebaseer is. Trouens, tot ' $n$ groot mate is Skrifgedeeltes bloot aanmekaar geryg. Dit is in lyn met Bucer se opmerking dat indien 'n belydenis gevorm word, dit kort moes wees en uit die Skrif saamgestel word.

Elke artikel is opgebou volgens 'n bepaalde patroon. Daar word begin met ' $n$ belydenis oor God. Met bekende aanhalings uit die $\mathrm{Ou}$ - en Nuwe Testament word God se dade, wat van toepassing is op die tema wat behandel word, vertel. Hierna volg in al die artikels, behalwe die eerste een, dat die kerk geroep word om God te volg ten opsigte van die betrokke saak van die artikel. Weer eens volg Bybelgedeeltes en dan enkele konkretiserende sake (uitgesonder artikel 1 en 5). By artikels 2, 3 en 4 volg ten slotte 'n samevattende afwysing. 
Net soos die gebruik van godsdienstige taal en vroom gewoontes nie 'n bewys van egte godsvrug is nie, is die blote gebruik van Skrifgedeeltes nie 'n bewys dat dit God se wil uitdruk nie. Ons uitsprake oor God is in elk geval metafore en van voorlopige aard. Ons denke, ook ons teologiese denke, en ons keuse van tekste is nog aan die "sondeval" onderworpe. Ons is geneig om ons eie behoeftes en belange voorop te stel, maar dan te kamoefleer met godsdienstigheid en vroomheid. Let maar op wie wat verdedig. Onder vroom argumente skuil dikwels niks anders as selfbelange en eiegeregtigheid nie.

Word die Skrif deur Die Belydenis gebruik om eie opvattinge te legitimeer? D J Smit ${ }^{20}$ beskryf die Skrifgebruik as "Bybelse assosiasies" en meen hy dat die genre van 'n belydenis van geloof die "Bybelse droom" wat 'n uitsig bied, koers verskaf en inspireer, maar wat ook as "kritiese toets" dien, bevat. Van absolutisme in die sin van 'n fundamentalisme of 'n konfessionalisme is hier nie sprake nie. Die Belydenis wil die weg open tot Skrifwaarhede wat in ons tyd aktueel geword het. Hier is geen a-historiese beskouing oor die Skrif of Skriftoepassing nie.

Dat die konteks (naas die teks) 'n beslissende rol speel word eksplisiet erken ${ }^{21}$. Anders as wat dikwels die geval is word die invloed van omstandighede op die Bybelinterpretasie erken. Smit ${ }^{22}$ erken dat die analise van die situasie deurslaggewend is en dat geen "waarborg, formele of objektiewe kriteria" bestaan dat dit korrek gepeil is nie. Net soos die Brief (paragraaf 2) praat hy van 'n “onvermydelike waagstuk". Christene kan hulle hoogstens beroep op "die klaarblyklikheid van die evangelie, moontlik op die konsensus sonder Christene en kerke, en in laaste instansie op hulle eie oortuigings en gewete in verantwoordelikheid voor God" aldus $\mathrm{Smit}^{23}$. Durand ${ }^{24}$ is oortuig dat daar algemene konsensus is oor die dwaalleer met 'n rassistiese oorsprong: "As daar een saak is waaroor daar sedert die Tweede Wêreldoorlog groot eenstemmigheid onder kerke van alle groeperinge bestaan, dan is dit 'n gemeenskaplike afkeer van alle vorme van rassisme".

Die drie sentrale temas oor eenheid, versoening en geregtigheid word behandel met 'n finaliteitskarakter wat 'n belydenis kenmerk. Die paradoks met die uitsprake dat Die Belydenis 'n waagstuk is, is nie daarin geleë dat die saak wat bely word twyfelagtig is nie, maar dit hang saam met die selfkritiese gees waarin Die Belydenis gegee word. Skuld word bely volgens Die Belydenis (Brief paragraaf 1). Daar is 'n sterk bewussyn dat ander ("geldende") motiewe, groepsbelange of teologieë nie gedien wil word nie en daar word gepleit dat dit nie misbruik word nie, maar dat God die diepste motiewe moet beoordeel (Brief paragraaf 2). Die Belydenis is 
nie gerig teen spesifieke mense of kerke nie, maar teen 'n valse leer wat ook implikasies van selfondersoek het (Brief paragraaf 3).

Die noodsaak van Die Belydenis kom voort uit 'n bepaalde konteks waarin baie ernstig geoordeel word dat die eenheid van die kerk, die versoening in Christus en die geregtigheid van God deur 'n dwaalleer bedreig word. Die normatiewe krag van Die Belydenis kom egter uit die teks van die evangelie van Jesus Christus. Die konteks word as beide ernstig en mede-bepalend beskou. Die klem op teks en konteks lei nie tot 'n selfregverdigende absolutisme nie.

\section{SOU DIE BELYDENIS NOG RELEVANT WEES?}

Dit is duidelik dat Die Belydenis histories gewortel is. Sou die karakter en inhoud sodanig wees dat die "Bybelse assosiasies" die gehalte van 'n Goddelike rigtingwyser het ook vir nuwe sosio-politieke omstandighede wat verskil van 1982 en 1986 ? Slegs twee voorbeelde word bespreek. Die eerste is 'n sinsnede wat die historiese realiteit beklemtoon terwyl die tweede terme is wat die historiese realiteit wil relativeer ten gunste van 'n bo-historiese kwaliteit.

\section{1 "In so 'n situasie..."?}

Wat nie duidelik is uit Die Belydenis nie, is of die kerk ten alle tye gewone rasseskeiding vanuit die evangelie mag goedpraat en of dit net in 'n spesifieke situasie nie goedgepraat mag word nie? Die kwalifiserende sinsnede - "in so 'n situasie" (artikel 3.5) - is onduidelik en verwarrend.

Indien die sinsnede sou teruggryp op artikel 3.3 waar die situasie beskryf word as "in 'n land wat op Christelikheid aanspraak maak" sou dit beteken dat teologiese regverdiging net in sogenaamde "Christelike" lande verkeerd sou wees. Dit sou dan in teëspraak wees met artikel 4.3 waar "...volgelinge van Christus moet getuig teenoor alle magtiges en bevoorregtes" - dus ongeag of hul in "n Christenland woon of Christene is. Dit is verder in teëspraak met artikel 5 waarin ook van ongekwalifiseerde volharding gespreek word: “... al sou ook die owerhede en verordeninge van mense daarteen wees en al sou straf en lyding daaraan verbonde wees".

Die klem lê op die "gedwongenheid" van skeiding. Nicol25 is reg dat "in so 'n situasie" verwys na al die kwade gevolge - vervreemding, haat vyandskap, vooroordeel, vrees en selfsug (3.3 en 3.4) - wat gedwonge skeiding het. Dit gaan nie hier om 'n altyd geldende staatsteorie nie, maar 
om die beskrywing van 'n samelewings-realiteit. Die sinsnede "in so 'n situasie" is dus nie 'n voorwaardelike kwalifikasie nie, maar 'n verdere omskrywing van 'n realiteit. Hieruit kan wel afgelei word dat die kerk dwangmaatreëls deur die staat wat "van bo" op mense afgedwing word moet teëstaan. So 'n interpretasie is in ooreenstemming met artikel 4.4 waar "enige ideologie" wat verontregting legitimeer, teëgestaan word. Dit is verder ook in ooreenstemming met die karakter van Die Belydenis wat gerig is teen "dwang" (artikel 2.6), asook "verabsolutering" (artikel 2.8) en wat roep om vryheid (artikel 2.6). Terwyl skeiding in die kerk in alle gevalle volgens Die Belydenis verkeerd is, kan geen afleiding gemaak word dat skeiding in die samelewing, wat sonder dwang geskied in alle gevalle verkeerd is of sal wees nie. Alle skeiding wat die kerk se versoeningstaak belemmer, word teengestaan. Hieruit is dit duidelik dat die historiserende element gekwalifiseer is om Die Belydenis 'n bo-historiese karakter te gee.

\section{2 "Gedwonge skeiding"}

Dit is opmerklik dat apartheid nie by die naam genoem word nie. Die redes hiervoor is dat dit in die aard van belydenistaal, wat die omstandighede van die tyd te bowe wil gaan, nie wenslik is nie. 'n Tweede rede is, volgens Durand ${ }^{26}$, dat die opstellers wou klem lê op die kerklike dwaalleer van gedwonge skeiding wat die apartheidstelsel ten grondslag lê. 'n Derde moontlike rede is dat vir gedwonge skeiding 'n hele aantal begrippe bestaan naamlik segregasie, apartheid, afsonderlike ontwikkeling, afsonderlike vryhede, partisie, eiesoortige ontwikkeling, groepsafbakening, eie gemeenskapslewe ensovoorts. Deur die saak te omskryf as "gedwonge skeiding" op grond van ras of kleur het hulle enige misverstand, maar ook enige rasionalisasie met woorde afgewys.

Hoewel die term sosiale realiteit wil onthistoriseer is ek nie seker of dit so suksesvol in die toekoms sal kommunikeer nie. Talle van die groot probleme in die wêreld bly weliswaar die magstryd tussen etniese groeperinge. 'n Halfmiljoen of meer Tutsis is in 1994 deur Hutus in Rwanda uitgewis. Die Serwiërs het in 1995 deur "etniese skoonmaak" die gruweldade van Hitler en Stalin herhaal. Die stryd tussen partye, stamme en selfs volke in KwaZulu-Natal toon 'n spiraal van geweld. Verder is daar 'n sluimerende rassisme by wit Suid-Afrikaners wat deur die ervaring van 'n "omgekeerde diskriminasie" tot uitbarsting kan kom soos by die neoNazi's in Duitsland. Die noemer "gedwonge skeiding" is vir hierdie realiteite nie genoegsaam veronthistoriseer nie.

Tog het die geheel van die argument 'n bo-historiese kwaliteit. Die onderskeid tussen mense op biologiese gronde (artikel 3) word in artikel 4 
vervang met juridiese terme: verontregtes en bevoorregtes. Dit word voor God bely dat enige vorm van verontregting bestry moet word. Die keuse is doelbewus gemaak vir verontregtes maar ook vir armes en noodlydendes (ekonomiese terme). Daarom word die indruk van 'n klassestryd en die eensydige interpretasie van die Bevrydingsteologie vermy. Die Bybelse oortuiging dat God in besonder die God van die hulpelose is, (wat ook in Kerk en Samelewing beklemtoon word), word hier bely. Nuwe uitvoerders en ontvangers van ongeregtigheid kan dus hierdeur aangespreek word. Indien Die Belydenis 1986 as Belydenisskrif erken sou word, sal lidmate wat tans deur onregverdige regstellende aksies benadeel is, deur 'n sterker geloofsbasis ondersteun word. Wat die ander twee hoofsake van die belydenis betref, naamlik kerkeenheid en versoening, is dit duidelik dat dit relevant sal bly.

\section{GEVOLGTREKKING EN SLOT}

Ons sou 'n geleentheid vir geloofwaardige kerkwees weer laat verbygaan indien ons nie Die Belydenis 1986 sou aanvaar nie. Hierdie is 'n geleentheid om nie net weer ons ortodoksie te toon, nie maar ook ons ortopraksie te bely. Die spreekwoord lui: "The proof of the pudding is in the eating". Ons skuldbelydenis (Rustenburg en elders) word nou getoets.

Die Verenigende Gereformeerde Kerk sal om verstaanbare redes Die Belydenis 1986 nie laat vaar nie. Kleinlike redes mag nie in die weg van kerkeenheid staan nie. Groot gewigtige redes kan nie teen Die Belydenis ingebring word nie. Ons moet weer erken: Die Belydenis is nie onskriftuurlik of teen die ander belydenisskrifte nie. Die Belydenis bied ons 'n geleentheid om in konfessionele taal ons op 'n pad van egte versoening in ons land te plaas.

Natuurlik sou ons teenstand verwag. 'n Belydenis oor dissipelskap en lewe kos 'n prys. Christene en dominees wat eie gewildheid bo integriteit stel, sal soos voorheen, die kwessie vermy. Vanweë sulke kortsigtigheid sal die kerk se lys ongeloofwaardighede op die lang termyn verder gedebiteer word. Diegene wat waagmoed het en wat in hulle pastoraat ook profeet wil wees, sal stry vir dit wat ander eerste as Reg geïdentifiseer het. Egte belydenis was nog nooit maklik gewees nie. In die woorde van Weber: "Sie [die Gemeinde - ACJvN] gibt sich im Bekenntnis selber auf. Das Bekenntnis ist daher denkbar ungeeignet, ein 'Boden' zu sein, aufdem man sich als Kirche behaupten könnte. Es ist ja van Haus aus auch im spezifische Sinne 'Martyrium'"28. 


\section{NOTAS:}

1 Hierdie referaat is gelewer by die Ned Geref Ring van Eloffsdal se bespreking oor kerkeenheid op 7 Augustus 1995. Gedeeltes van die referaat is 'n verwerking uit my ongepubliseerde DD-proefskrif: Kontekstualiteit in die SuidAfrikaanse sosiale etiek, Universiteit van Pretoria 1989.

2 So byvoorbeeld by G Gloege, "Bekenntnis (Dogmatisch)", in: Die Religion in Geschichte und Gegenwart, Bd I, Tübingen 31957, 994-999; H Schröer, "Glaubensbekentnisse (Praktisch-theologisch)", in: Theologische Realenzyklopädie, Bd XIII, Belin 1984, 441-446; J Wirsching, "Bekenntniss schriften", in: Theologische Realenzyklopädie, Bd V, Berlin 1980, 487-511; en O Weber Grundlagen der Dogmatik, Bd I, Neukirchener-Vluyn 41972, 38-43.

$3 \quad$ Weber, $a w, 39$.

$4 \quad$ J A Heyns, Die kerk, Pretoria 1977, 153.

5 H Schwarz, "Glaubensbekentnisse (Geschichtlich)", in: Theologische Realenzyklopädie, Bd XIII, Berlin 1984, 437-441.

$6 \quad$ Vergelyk C Augustijn, Kerk en belijdenis, Kampen 1971, 29-36.

$7 \quad$ Augustijn, $a w, 60$.

$8 \quad$ Augustijn, $a w, 68-74$.

$9 \quad$ Vergelyk Heyns, $a w, 162$.

10 J W Hofmeyr en E A van Niekerk, "Die Nederlandse Geloofsbelydenis: Konteks en Teks", in: H L Bosman en J W Hofmeyr (reds), Die Nederlandse Geloofsbelydenis: Ontstaan, Skrifgebruik en gebruik, Pretoria 1987, 1-13.

11 Wirsching, $a w, 506$.

12 Augustijn, $a w, 47-50$.

13 Vergelyk Augustijn, $a w, 56-57$ en ook J J F Durand, "'n Belydenis - was dit werklik nodig?", in: G D Cloete en D J Smit (reds), 'n Oomblik van waarheid: Opstelle rondom die NG Sendingkerk se afkondiging van 'n status confessiones en die opstel van 'n konsepbelydenis, Kaapstad 1984, 39.

14 Weber, $a w, 42$.

15 Heyns, $a w, 154-155$. 
$16 \mathrm{~J}$ W V van Huyssteen, "Belydenis as denkmodel - 'n teologie tussen insig en ervaring", in: D J Smit (red), Teologie - Belydenis - Politiek (Referate van die Dogmatologiese Werkgemeenskap), Bellville 1984.

17 Vergelyk Weber, $a w, 40$.

18 Vir 'n hersiening van die tradisionele interpretasie deur die Nederduitse Gereformeerde Kerk se navorsers kan die bundel van J Kinghorn, Die NG Kerk en apartheid, Johannesburg 1986 geraadpleeg word. Veral C F A Borchardt se bydrae het betrekking.

19 D P M Huet, Ene kudde en een herder: Verhandeling over de toebrenging van heidenen tot de Christelijke kerkgemeenschap, Kaapstad 1860.

20 D J Smit, “...op 'n besondere wyse die God van die noodlydende, die arme en die verontregte...", in: D J Smit, $a w, 64-68$.

21 Vergelyk die eerste paragraaf van die begeleidende brief. Die begeleidende brief, (vervolgens Brief), wat 'n amptelike dokument van die NG Sendingkerk is en saam met die belydenis uitgegee is, word as gesaghebbend ten opsigte van die belydenis beskou en gevolglik saam bespreek.

22 D J Smit, “Wat beteken status confessiones?” in: G D Cloete en D J Smit, $a w$, 1984, 23-26.

23 Smit, $a w, 25$.

24 Durand, $a w, 47$.

25 W Nicol, "Antwoorde uit die NG Kerk op die Konsepbelydenis 1982", Voordrag gelewer by 'n Reforum byeenkoms, Pretoria 1984.

26 Durand, $a w, 46$.

27 Durand $a w, 43$.

$28 \quad$ Weber, $a w, 39$. 